\title{
Alberta creates electronic registry for personal directives
}

$\mathrm{W}$ hen Caroline Marion drafted her living will in 2006, she named her husband and a friend as her agents should she be incapacitated by an accident or an illness. Then she filed the will away in a desk drawer.

But last month, Marion learned that she can register her personal directive online with the Alberta government, so that doctors and other health care workers can locate her agents immediately, even in the dead of night, if she cannot speak for herself. She promptly registered her document.

"It's a good idea," says Marion, a Parks Canada manager from Canmore, Alberta. "At the end of the day, with the registry, I think it will be more likely that our wishes will be honoured."

The Alberta registry, which can be used for health directives, advanced care directives and living wills, is the first province-wide electronic directory available 24/7 in Canada.

Administered by the Office of the Public Guardian, the registry does not contain the details of anyone's personal directive. It merely indicates whether a person has a directive, displays the date it was signed, and provides contact information for the individual and his or her agent(s), if any are named.

Health care workers can search the registry around the clock, but access is governed by legal agreements among the public guardian and Alberta's 9 health care regions (which will become 1 health authority later this year). The province's privacy commissioner vetted the registry's security measures, which include password access for authorized users and the electronic tracking of access, as well as the stipulation that users can only search for patients under their direct care.

The idea for an online registry - instead of one accessed by phoning a government office - arose during a 3-year public review of the province's Personal Directives Act. "Health care providers said a lot of emergencies happen outside of business hours," says Brenda Lee Doyle, director of the Office of the Public Guardian. "Everybody was saying: 'If I take the trouble to write a personal directive, I want the right people to know."'

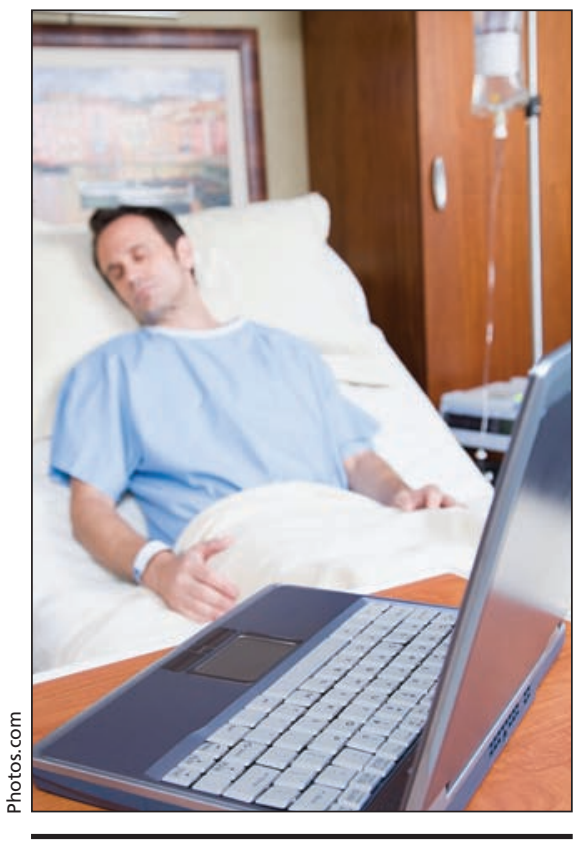

Alberta is the first Canadian province to establish a 24-hour, province-wide electronic registry for health directives, advanced care directives and living wills.

A handful of similar electronic registries exist in other countries, but "there's nothing similar in Canada at all," Doyle says.

The registry has been operating since June 2008, but of the estimated 100000 Albertans with personal directives, only a few thousand have registered them. In February, the Office of the Public Guardian launched an awareness campaign.

In Alberta, a directive can cover short-term or long-term incapacitation. People can register their directives through lawyers, or through the Public Guardian by phone or online at www.seniors.gov.ab.ca/opg/registry/.

Les Scholly, a lawyer in Medicine Hat, Alta., says his firm is promoting the registry to clients who make directives because it provides peace of mind. "It increases the likelihood that [the directive] will be found, and followed." Two of his middle-aged clients recently signed up, but he says it may be harder to convince older clients to put even a small amount of personal information in an electronic registry.

Traditionally, Scholly's clients have left living wills or other personal direc- tives with their lawyers or family members. But "if something happens to someone while a lawyer is on holiday, or family members ... are away, it certainly makes it more difficult to track it down," Scholly says. In Marion's case, she told her coworkers whom to contact in an emergency. If her husband is injured with her, or out of the country, she has left a friend in charge. But it could take authorities time to locate those people and the document.

"I can see a circumstance where something happened to both of us, and it might be difficult for the authorities to determine our wishes," says Marion. "Without the registry, it could take hours, or days."

Marion plans to spread the word to friends. "It just makes it easier to fulfill your wishes." - Christie McLaren, Canmore, Alta.

DOI:10.1503/cmaj.090256

\section{Briefly}

President-elect: Ottawa, Ontario, internist Dr. Jeff Turnbull has been selected president-elect of the Canadian Medical Association for 2010/11. Turnbull, who emerged as the victor in a 3candidate contest, is chief of staff at the Ottawa Hospital and a past president of the College of Physicians and Surgeons of Ontario. If ratified at this year's CMA conference, to be held in Saskatoon, Saskatchewan, Turnbull will assume presidential duties in August 2010.

Rights review: Some 68 countries stepped up with criticisms of Canada's human rights record during a United Nations Human Rights Council review last month in Geneva, Switzerland. The Draft Report on the Working Group of the Universal Periodic Review indicates that Canada's treatment of its indigenous peoples prompts the most concern, with several states urging that Canada reverse its opposition to the $2007 \mathrm{UN}$ Declaration on the Rights of Indigenous Peoples. - Wayne Kondro, CMAJ

DOI: $10.1503 / \mathrm{cmaj} .090346$ 